\title{
The Impact of Intellectual Capital on Bank Profitability during COVID-19: A Comparison with China and Pakistan
}

\author{
Jian Xu $\mathbb{D},{ }^{1}$ Muhammad Haris $\mathbb{D}{ }^{2}$ and Muhammad Irfan $\mathbb{D i D}^{2}$ \\ ${ }^{1}$ Department of Economics and Management, Qingdao Agricultural University, Qingdao 266109, China \\ ${ }^{2}$ Institute of Banking \& Finance, Bahauddin Zakariya University, Multan 60800, Pakistan \\ Correspondence should be addressed to Muhammad Haris; harmalik@outlook.com
}

Received 28 July 2021; Revised 16 November 2021; Accepted 20 January 2022; Published 8 February 2022

Academic Editor: A. Dionisio

Copyright (C) 2022 Jian Xu et al. This is an open access article distributed under the Creative Commons Attribution License, which permits unrestricted use, distribution, and reproduction in any medium, provided the original work is properly cited.

\begin{abstract}
This study aims to examine how the relationship between intellectual capital (IC) and bank profitability changed during COVID19. Based on the data of 34 Chinese banks and 39 Pakistani banks, this study uses ordinary least squares (OLS) to examine this relationship during the COVID-19 era. Profitability is measured by return on assets (ROA) and return on equity (ROE), and IC is measured by the value added intellectual coefficient (VAIC) model. The findings show that, even during the COVID-19 pandemic, IC has managed to sustain its positive influence on bank profitability in China and Pakistan. Among IC components, our study reports that human capital is the only IC resource that continues to enhance ROA and ROE of Chinese and Pakistani banks during the pandemic period. Our study suggests that policymakers should pay more attention to IC resources, which has the potential to improve banks' profitability even during crisis times.
\end{abstract}

\section{Introduction}

According to the World Health Organization (WHO), novel coronavirus disease 2019 (COVID-19) first appeared in December 2019 in Wuhan city, Hubei province of China. It seemed to catch global attention due to its rapid spread in January 2020. Despite the preventive steps taken by the Wuhan government, this disease spread across different cities other than Wuhan and later spread to various countries along with commuters. The WHO proclaimed the virus a global pandemic on 11 March 2020 and advised to take preventive actions. During this pandemic, almost all countries have had travel ban, reduced or stopped flight operations, and implemented nationwide lockdowns to control the spread of this virus [1]. Until 12 January 2022, COVID-19 infected nearly 308 million people and caused 5 million deaths. The continuous news coverage on current cases and deaths has created huge uncertainty for financial and commodity markets [2]. The COVID-19 crisis is causing not only turmoil in financial markets but also a downturn in real economies [3, 4]. According to the International Monetary Fund (IMF), the gross domestic product (GDP) of all major economies like USA, China, and the European Union, shrank during COVID-19 [5].

COVID-19 has disrupted the global economy since the great recession. Although protective precautions like social distancing and lockdowns have proven their essence to a large extent, they have a cost in terms of decreased business revenues and even the complete dissolution of different bodies. Scholars argued that financial markets are all highly exaggerated by major events $[6,7]$. Pakistan is one of those countries facing the worst situation due to the COVID-19 pandemic [8]. The first COVID-19 case was reported on 26 February 2020 in Karachi, and now more than 1.2 million cases were reported, with 28 thousand deaths. However, the rate of recovery is much better compared to developed countries like the USA, France, and Italy. Like other countries, the Pakistani government started to enforce lockdowns on 24 March 2020 to curtail the spread of COVID-19, permitting only vital industries and businesses to function.

In China, the COVID-19 pandemic started before the Spring Festival $[9,10]$. China has the biggest movement of population in the world, and a number of unique steps have 
been taken to prevent the virus from spreading [11]. According to Xiao et al. [12], nearly 11 million people have been put into lockdown. To keep away from an economic meltdown, the Chinese government has formulated a package of policies to help workers get back to work and allocated 110.48 billion yuan to prevent and control COVID-19 on 5 March 2020. On 16 March 2020, the Bank of China renewed the loan policy to companies, reduced the reserve ratio for banks, and announced a total of 550 billion yuan to support the economy.

Similarly, to offset the consequences of this economic shock, the Pakistani government implemented various stimulus policies. The government of Pakistan announced the economic package of PKR 1.2 trillion to provide relief to the slowed-down economy and food preservation for the common people. The COVID-19 crisis affects banking performance in many ways. First, the firms cease their operation due to the lockdown, and they might not repay their loans. In addition, employees who have lost their jobs are not able to pay off their debts. Second, when the value of bonds and other financial instruments drops, the banks are adversely affected, resulting in more declines in bank value. Third, banks are facing growing demands for loans, as businesses need additional cash flows to cover their expenses in the period of no or decreased revenues. Fourth, there is a supply shortage of various services, which reduces banks' noninterest income. In Pakistan, all banks operate under the umbrella of a central bank. To mitigate the impact of COVID-19, the State Bank of Pakistan (SBP) took different measures, such as a major reduction in the policy rate. The policy rate before COVID-19 was greater than 13\% and now stands between $7 \%$ and $8 \%$. The SBP allowed the banking sector to provide additional loans and reduce the capital conservation buffer from $2.50 \%$ to $1.50 \%$. The SBP announced cheap loans for hospitals and medical centres at the rate of 3\% for 5 years under Refinance Facility for Combating COVID-19 and refinance scheme for payment of wages and salaries to all types of workers and employees. The SBP urged banks to follow the required practices to tackle the spread of COVID-19 and ensure the availability of continuous financial service facilities and also instructed banks to keep minimum staff for the continuity of essential banking services. In order to minimize the spread of COVID-19 by prohibiting citizen's physical contact in bank branches, the SPB has urged banks to waive all fees for funds transfer via online banking platforms such as interbank fund transfer.

The preventing measures taken by the Chinese and Pakistani governments also influence the performance of the banking sector in different ways. First, the banking sector did not operate at its full potential because of the strict lockdown policy, and the continuous growth of this sector was decelerated, which concerned the value of intellectual resources. Second, the reduction in the policy rate by regulators also lowers the expected profitability of banks, which ultimately reduces bank value. Third, some policies, such as the work-from-home policy, disabled the banks' employees from creating efficiency, which influences bank value and profitability. Finally, the loan restructuring and inability of loan repayments by the firms because of the bumpy operations affect the banks' value, thus reducing bank profitability. Despite these influences, many theorists and researchers [13-16] argued that intangible resources, particularly intellectual capital (IC), are the most significant resources that prevent shocks from different crises. However, we are uncertain about whether IC was defensive in protecting the profitability of Chinese and Pakistani banks from the shocks of COVID-19 or not. Therefore, this study is designed to offer insights into the impact of IC on bank profitability in the two countries during the pandemic period. This study employs Pulic [17]'s value added intellectual coefficient (VAIC) model to measure IC based on the quarterly data from 2020 Q1 to 2020 Q3.

The contributions of the current study are as follows. First, it is the first study that analyzes and compares the impact of IC on bank profitability during the COVID-19 pandemic in two Asian emerging economies, i.e., China and Pakistan. Although previous studies have already examined the relationship between IC and bank profitability, the relevant study related to COVID-19 is not available yet. Second, understanding the impact of COVID-19 is important for bank managers and policymakers to get insight into the role of IC in guarding profitability during the crises period.

The remainder of this article is structured as follows: a literature review is presented in Section 2. Section 3 presents the research methodology, and Section 4 summarises the findings of this study. Section 5 discusses the findings, and Section 6 concludes the study.

\section{Literature Review}

2.1. Definition of IC. The most common concept of IC is that "any knowledge that can be converted into value" [18]. There is still no universal definition of IC $[19,20]$ because academics and practitioners have put forward a slew of IC concepts over the decades. According to Dean and Kretschmer [21], IC is linked to a firm's ability to generate, execute, and quantify intangible capital in order to increase value; in fact, this enhances the firms' efficiency. Recently, IC is defined as intellectual material, knowledge, information, intellectual property, and experience that can be put to use to create value [22].

The academics have divided IC into human capital (HC), structural capital (SC), and relational capital (RC). HC is embedded in people, including the knowledge, skills, expertise, and capabilities of employees in the firm [23]. HC is generally considered the most relevant element of IC [24]. SC encompasses organizational structures, procedures, processes, databases, culture, and the like [25]. It supports HC, which can boost employees to create and share knowledge [26]. RC refers to the relationships with customers, other stakeholders, and society as a whole [27, 28]. It can generate trust in the firm and influence the perceptions of external stakeholders [29, 30].

Researchers have developed several methods to measure IC. Although the VAIC model proposed by Pulic [17] has some limitations, it is widely used because of its simplicity, reliability, and standardization [31]. It also allows comparison across organizations or countries [31]. 
2.2. IC and Bank Performance. The impact of IC on bank profitability is a transparent and straightforward concept. A number of researchers have identified a significant direct association between IC and its components and bank profitability [32-39]. For example, Saengchan [32] found that IC has a strong relationship with the ROA of Thai commercial banks. Using the sample of banks in Bahrain from 2005 to 2007, Ismail and Karem [33] argued that IC has a positive impact on banks' financial performance. Meles et al. [34] used the data of US banks from 2005 to 2012 and found that IC positively affects bank performance. Mohammad et al. [35] analyzed the IC performance of Saudi banks and found that HC has a higher efficiency than physical capital and SC. Tran and Vo [36], taking Thai banks over the period 1997-2016 as the sample, stated that bank profitability is mainly influenced by physical capital and HC in the current year has a negative relationship with profitability. However, the comparison of IC efficiency in the banking sector across countries is still scarce in the current literature [37, 38]. The findings of Xu et al. [37] revealed that physical capital contributes the most to bank profitability in China and Pakistan.

In the banking sector, the VAIC method has been widely used to examine the impact of IC on corporate performance measured by profitability, efficiency, market value, and growth rate. For example, Chen Goh [40] applied the VAIC model to evaluate the IC performance of Malaysian commercial banks over a period of 2001-2003. He found that HC makes a large contribution to value creation in domestic and foreign banks of Malaysia, while domestic banks are more efficient in terms of value creation than foreign banks. Mondal and Ghosh [41] conducted a longitudinal study of 65 Indian banks for the period of 1999-2008. They pointed out that IC positively influences ROA in eight years, while IC positively influences ROE in three years out of ten years period. Joshi et al. [42] found that Australian bank performance is highly influenced by HC, while physical and structural capitals play a minor role in value creation. The findings of Vo and Tran [43] showed that the performance of listed banks in Vietnam is driven primarily by physical capital.

\subsection{IC and Bank Performance during Crisis. The relationship} between IC and organizational performance is becoming progressively prevalent, particularly in periods of intense economic turmoil. Starting from the first quarter of 2020, the recent financial crisis continues to disrupt the financial system. It is reported that the US financial sector fell dramatically due to the COVID-19 pandemic [44]. Before the COVID-19 pandemic, some studies have already been carried out on the relationship between IC and bank performance during crisis time. Based on the VAIC model, Sumedrea [45] examined the relationship between IC and economic performance during crisis time and found that $\mathrm{HC}$ and SC influence firm performance. A study of 191 banks during the period of 2000-2011 by Kehelwalatenna [15] showed that the impact of IC on firm performance was inconsistent during the 2008 financial crisis because of HC.
Sannino et al. [46], using the sample of Italian banks from 2012-2018, studied the relationship between IC and performance during and after the nonperforming loans (NPLs) crisis. The results revealed that IC positively influences financial performance irrespective of the NPLs crisis.

The debate about IC and bank performance is still an ongoing mission for further exploration $[34,36]$. Previous studies have yielded mixed results, and little has been done with the consideration of the impact of crisis time, indicating that further research is needed to better understand how banks can manage IC resources to boost their profitability during the COVID-19 period. The adverse impact of COVID-19 on banks is much more pronounced and longlasting than on companies $[47,48]$. Various reforms have impacted the banking industry and imposed new ways to improve the quality of services. Accordingly, the current study aims to expand awareness of the contribution of IC in the Chinese and Pakistani banking sector in order to effectively use intangible assets to generate value and achieve better financial performance during crises.

\section{Methodology}

3.1. Data. The sample for this study includes 34 Chinese banks and 39 Pakistani banks. Banks with missing information are excluded from our sample. To examine the impact of IC on banks' profitability during COVID-19, we collect the data for the first three quarters of 2020. COVID19 started in Wuhan, China, in November or December of 2019 and spread to the rest of the world in 2020. The final sample includes 219 bank-year observations. The data of Chinese banks are sourced from the CSMAR database, and the data of Pakistani banks are collected from the quarterly financial statements published on the websites of respective banks.

\subsection{Variables}

(1) Dependent Variables. The profitability of Chinese and Pakistani banks is measured by two important indicators, which have been extensively used in existing studies [36-38, 49-60]. The first indicator is the return on assets (ROA), calculated as the ratio of net income to average total assets. ROA shows the efficient utilization of all available assets that a bank has [61]. The second indicator is the return on equity (ROE), calculated as the ratio of net income to average shareholders' equity. ROE shows the effective utilization of funds invested by a bank owner.

(2) Independent Variables. This study uses Pulic [17]'s VAIC model to measure IC efficiency of listed banks, consistent with Meles et al. [34], Tran and Vo [36], $\mathrm{Xu}$ et al. [38], Mondal and Ghosh [41], Vo and Tran [43], Ousama et al. [62], and Le and Nguyen [63]. The VAIC model identifies banks with profitability in maximizing their economic performance in the process of value creation. In order to access the IC results, the VAIC model uses items from audited financial statements. Capital employed efficiency 
(CEE) measures how much value has been created per dollar of capital employed. Human capital efficiency (HCE) measures how much value has been created by one invested unit of $\mathrm{HC}$, and structural capital efficiency (SCE) shows how much capital has been created by SC. The equation to calculate VAIC is given as follows:

value added $(\mathrm{VA})=$ operating profits + employee cost

+ depreciation + amortization,

$$
\mathrm{CEE}=\frac{V A}{\text { book value of assets }}
$$

$$
\begin{aligned}
\mathrm{HCE} & =\frac{V A}{\text { employee costs }} \\
\mathrm{SCE} & =\frac{V A-\text { employee costs }}{V A},
\end{aligned}
$$

$$
\mathrm{VAIC}=\mathrm{CEE}+\mathrm{HCE}+\mathrm{SCE} .
$$

(3) Control Variable. This study uses three main variables in the analysis to control for certain bank characteristics: bank size (SIZE), measured by the natural logarithm of total assets; debt ratio (LEV), measured by the ratio of total liabilities to total assets; ownership (OWN), measured using binary values of 0 and 1 . It takes 1 if a bank is government-owned and 0 otherwise. The list of variables used in this study is mentioned in Table 1.

3.3. Models. We propose four models to examine the relationship between IC and its components and bank profitability during the pandemic period. Models (1) and (2) test the association between the integrated IC and bank profitability, while Models (3) and (4) test the relationship between IC components and bank profitability.

$$
\begin{aligned}
\mathrm{ROA}_{i, t} & =\beta_{0}+\beta_{1} \mathrm{VAIC}_{i, t}+\beta_{2} \mathrm{SIZE}_{i, t}+\beta_{3} \mathrm{LEV}_{i, t}+\beta_{4} \mathrm{OWN}_{i, t}+\varepsilon_{i, t}, \\
\mathrm{ROE}_{i, t} & =\beta_{0}+\beta_{1} \mathrm{VAIC}_{i, t}+\beta_{2} \mathrm{SIZE}_{i, t}+\beta_{3} \mathrm{LEV}_{i, t}+\beta_{4} \mathrm{OWN}_{i, t}+\varepsilon_{i, t}, \\
\mathrm{ROA}_{i, t} & =\beta_{0}+\beta_{1} \mathrm{CEE}_{i, t}+\beta_{2} \mathrm{HCE}_{i, t}+\beta_{3} \mathrm{SCE}_{i, t}+\beta_{4} \mathrm{SIZE}_{i, t}+\beta_{5} \mathrm{LEV}_{i, t}+\beta_{6} \mathrm{OWN}_{i, t}+\varepsilon_{i, t}, \\
\mathrm{ROE}_{i, t} & =\beta_{0}+\beta_{1} \mathrm{CEE}_{i, t}+\beta_{2} \mathrm{HCE}_{i, t}+\beta_{3} \mathrm{SCE}_{i, t}+\beta_{4} \mathrm{SIZE}_{i, t}+\beta_{5} \mathrm{LEV}_{i, t}+\beta_{6} \mathrm{OWN}_{i, t}+\varepsilon_{i, t},
\end{aligned}
$$

where $i$ represents the individual bank; $t$ represents the year; $\beta$ stands for the presumed parameter; and $\varepsilon$ denotes the standard error.

\section{Results}

4.1. Descriptive Statistics. The comparison of the descriptive statistics between China and Pakistan is presented in Table 2. The mean ROA of Chinese and Pakistan banks are 0.008 and 0.003 , respectively. Similarly, the mean ROE of Chinese and Pakistani banks is 0.106 and 0.059 , respectively. This shows that Chinese banks are more profitable than Pakistani banks during the COVID-19 outbreak. In addition, there are great differences in terms of profitability in these two countries. The mean VAIC of Chinese banks is 4.477 and the mean VAIC of Pakistani banks is 3.039, suggesting that Chinese banks are more capable of getting higher IC performance than Pakistani banks during such crisis. Regarding IC components, the mean HCE (3.700) and the mean SCE (0.687) of Chinese banks are higher than the mean HCE (2.353) and the mean SCE (0.433) of Pakistani banks, which implies that Chinese banks are more efficient to deal with human and structural capitals than Pakistani banks during the COVID-19 outbreak. However, the efficiency of capital employed in Pakistani banks is found to be higher than that in Chinese banks because the mean CEE (0.090) of Chinese banks is less than the mean CEE (0.229) of Pakistani banks.

In addition, the scale of Chinese banks is much larger than that of Pakistani counterparts. Chinese listed banks have higher financial risks with a higher level of debt. About 20 percent of these banks are owned by the government in both countries.

4.2. Empirical Results. Empirical results of this study are stated in Tables 3 and 4 . Table 3 provides the relationship between IC and profitability indicators (ROA and ROE). In the full sample, we find that the coefficients of VAIC are positive and significant $(\beta=0.003, t=6.650 ; \beta=0.014$, $t=5.503)$. One unit increase in the investment in IC brings 0.003 positive changes in ROA and 0.014 positive changes in ROE. This suggests that, during COVID-19, IC continued its positive influence on the profitability of the Chinese and Pakistani banking industry. It is worth noticing that the influence of IC on ROE is greater than its impact on ROA during the pandemic period.

In the Chinese banking sector, the positive coefficients of VAIC suggest that one unit increase in IC leads to the increased ROA by 0.001 and ROE by 0.009 . IC of Chinese banks sustained its positive influence on the profitability even during the pandemic period. However, IC has a higher impact on ROE than ROA. Xu et al. [38] also reported a positive relationship between IC and bank performance (measured through ROA and ROE) during the period of 2010-2018.

The results of Pakistani banks show that one unit increase in IC brings 0.006 positive changes in ROA and 0.028 positive changes in ROE. Hence, it is evidenced that the IC of 
TABLE 1: Variable definition.

\begin{tabular}{lcc}
\hline Variable & Notation & Measurement \\
\hline Return on assets & ROA & Net income/average total assets \\
Return on equity & ROE & Net income/average shareholders' equity \\
Value added intellectual coefficient & VAIC & See (1) \\
Capital employed efficiency & CEE & See equation (2) \\
Human capital efficiency & HCE & See equation (3) \\
Structural capital efficiency & SCE & See equation (4) \\
Bank size & SIZE & Natural logarithm of total assets of listed banks \\
Debt ratio & LEV & Total liabilities/total assets \\
Ownership & OWN & Dummy variable that takes 1 for government-owned banks, 0 otherwise \\
\hline
\end{tabular}

TABle 2: Descriptive statistics of banks in China and Pakistan.

\begin{tabular}{|c|c|c|c|c|c|c|c|c|c|c|c|}
\hline \multirow{2}{*}{ Variable } & \multicolumn{5}{|c|}{ China } & \multicolumn{5}{|c|}{ Pakistan } & \multirow{2}{*}{ Difference $t$-statistics } \\
\hline & $\mathrm{N}$ & Mean & Max & Min & $\mathrm{SD}$ & $\mathrm{N}$ & Mean & Max & Min & $\mathrm{SD}$ & \\
\hline $\mathrm{ROA}$ & 102 & 0.008 & 0.025 & -0.013 & 0.005 & 117 & 0.003 & 0.168 & -0.083 & 0.025 & $-2.014^{* * *}$ \\
\hline $\mathrm{ROE}$ & 102 & 0.106 & 0.167 & -0.049 & 0.035 & 117 & 0.059 & 1.059 & -0.134 & 0.115 & $-4.007^{* * *}$ \\
\hline VAIC & 102 & 4.477 & 18.794 & 2.252 & 2.431 & 117 & 3.039 & 11.558 & -3.836 & 2.020 & -4.780 \\
\hline CEE & 102 & 0.091 & 0.181 & 0.012 & 0.039 & 117 & 0.229 & 3.094 & -0.023 & 0.303 & $4.586^{* * *}$ \\
\hline HCE & 102 & 3.700 & 17.691 & 1.761 & 2.358 & 117 & 2.353 & 10.381 & -0.821 & 1.587 & -4.929 \\
\hline SCE & 102 & 0.687 & 0.943 & 0.432 & 0.095 & 117 & 0.433 & 2.421 & -4.060 & 0.775 & $-3.284^{* * *}$ \\
\hline SIZE & 102 & 27.897 & 31.142 & 21.861 & 2.046 & 117 & 18.377 & 21.936 & 12.090 & 2.616 & $-29.682^{* * *}$ \\
\hline LEV & 102 & 0.914 & 0.940 & 0.722 & 0.037 & 117 & 0.861 & 4.806 & 0.025 & 0.430 & $-1.244^{* * *}$ \\
\hline OWN & 102 & 0.206 & 1 & 0 & 0.406 & 117 & 0.215 & 1 & 0 & 0.406 & -0.014 \\
\hline
\end{tabular}

Note: ${ }^{* * *} p<0.01$.

Table 3: Regression results of Models (1) and (2).

\begin{tabular}{lcccccc}
\hline \multirow{2}{*}{ Variable } & \multicolumn{2}{c}{ Full sample } & \multicolumn{2}{c}{ China } & \multicolumn{2}{c}{ Pakistan } \\
& Model $(1)$ & Model $(2)$ & Model $(1)$ & Model $(2)$ & Model (1) & Model (2) \\
\hline Constant & $-0.025^{* * *}(-5.015)$ & $-0.078^{* * *}(-2.936)$ & $-0.074^{* * *}(-12.150)$ & $-0.604^{* * *}(-11.123)$ & $0.003(0.248)$ & $-0.127^{*}(-1.884)$ \\
VAIC & $0.003^{* * *}(6.650)$ & $0.014^{* * *}(5.503)$ & $0.001^{* * *}(14.249)$ & $0.007^{* * *}(7.598)$ & $0.006^{* * *}(6.037)$ & $0.028^{* * *}(5.632)$ \\
SIZE & $0.000(-1.158)$ & $0.004^{* * *}(3.268)$ & $0.000(-0.896)$ & $-0.001(-0.513)$ & $-0.002^{* * *}(-3.151)$ & $0.004(1.120)$ \\
LEV & $0.029^{* * *}(8.771)$ & $0.033^{*}(1.882)$ & $0.086^{* * *}(11.027)$ & $0.763^{* * *}(10.915)$ & $0.029^{* * *}(6.739)$ & $0.017(0.782)$ \\
OWN & $-0.004(-1.429)$ & $-0.007(-0.486)$ & $0.000(0.585)$ & $-0.006(-1.014)$ & $-0.002(-0.401)$ & $0.035(1.439)$ \\
$N$ & 219 & 219 & 102 & 102 & 117 & 117 \\
Adj. $R^{2}$ & 0.364 & 0.225 & 0.759 & 0.644 & 0.425 & 0.251 \\
$F$ & $32.244^{* * *}$ & $16.788^{* * *}$ & $80.369^{* * *}$ & $46.644^{* * *}$ & $22.473^{* * *}$ & $10.730^{* * *}$ \\
\hline
\end{tabular}

Note: ${ }^{*} p<0.10,{ }^{* *} p<0.05$, and ${ }^{* * *} p<0.01 . t$-values are in parentheses.

TABLe 4: Regression results of Models (3) and (4).

\begin{tabular}{lcccccc}
\hline \multirow{2}{*}{ Variable } & \multicolumn{2}{c}{ Full sample } & \multicolumn{2}{c}{ China } & \multicolumn{2}{c}{ Pakistan } \\
& Model $(3)$ & Model $(4)$ & Model $(3)$ & Model $(4)$ & Model $(3)$ & Model $(4)$ \\
\hline Constant & $-0.027^{* * *}(-5.114)$ & $-0.158^{* * *}(-10.836)$ & $-0.074^{* * *}(-14.247)$ & $-0.590^{* * *}(-10.387)$ & $-0.004(-0.348)$ & $-0.067^{* *}(-2.247)$ \\
CEE & $0.003(0.598)$ & $0.300^{* * *}(24.184)$ & $0.004(0.824)$ & $0.063(1.065)$ & $0.004(0.780)$ & $0.320^{* * *}(23.225)$ \\
HCE & $0.004^{* * *}(6.959)$ & $0.004^{* * *}(2.960)$ & $0.002^{* * *}(16.371)$ & $0.009^{* * *}(5.684)$ & $0.009^{* * *}(7.244)$ & $0.011^{* * *}(3.847)$ \\
SCE & $-0.001(-0.618)$ & $0.036^{* * *}(6.938)$ & $-0.023^{* * *}(-6.807)$ & $-0.049(-1.314)$ & $-0.002(-0.949)$ & $0.038^{* * *}(6.649)$ \\
SIZE & $0.000(-0.919)$ & $0.007^{* * *}(11.437)$ & $0.000^{* *}(2.116)$ & $0.000(0.217)$ & $-0.002^{* * *}(-3.126)$ & $0.000(0.140)$ \\
LEV & $0.030^{* * *}(9.102)$ & $0.000(-0.019)$ & $0.089^{* * *}(13.208)$ & $0.749^{* * *}(10.096)$ & $0.032^{* * *}(7.644)$ & $-0.003(-0.297)$ \\
OWN & $-0.004(-1.647)$ & $0.014^{* *}(2.051)$ & $0.000(0.195)$ & $-0.006(-1.064)$ & $0.000(-0.098)$ & $0.043^{* * *}(4.011)$ \\
$N$ & 219 & 219 & 102 & 102 & 117 & 117 \\
Adj. $R^{2}$ & 0.375 & 0.791 & 0.841 & 0.647 & 0.481 & $18.953^{* * *}$ \\
$F$ & $22.755^{* * *}$ & $138.748^{* * *}$ & $90.287^{* * *}$ & $31.866^{* * *}$ & $116.748^{* * *}$ \\
\hline
\end{tabular}

Note: ${ }^{*} p<0.10,{ }^{* *} p<0.05$, and ${ }^{* * *} p<0.01 . t$-values are in parentheses. 
Pakistani banks is a positive driver of profitability indicators even when the world is facing a hilarious situation because of the COVID-19 pandemic. These results are consistent with Yao et al. [37] and Haris et al. [52], who found a positive influence between IC and ROA and ROE during the period of 2007-2018. Overall, the results reveal that, during this pandemic, IC has a higher impact on bank profitability in Pakistan than in China.

Table 4 provides the relationship between IC components and profitability indicators (ROA and ROE) during the pandemic period. The results of the full sample show that CEE has an insignificant positive association with ROA and a significant positive association with ROE. HCE has a positive and significant impact on both ROA and ROE. SCE has a positive impact only on ROE at the $1 \%$ level. Overall, $\mathrm{HC}$ is still the main contributor to profitability compared to physical and structural capitals when facing this devastating crisis.

In the Chinese context, HCE remains significantly and positively associated with $\operatorname{ROA}(\beta=0.004, t=0.824)$ and $\operatorname{ROE}(\beta=0.063, t=1.065)$. However, the impact of SCE on $\mathrm{ROA}$ is found to be negative $(\beta=-0.023, t=-6.807)$. Physical capital has no impact on bank profitability. Therefore, the findings suggest that $\mathrm{HC}$ is the only IC resource that continues raising the profitability of Chinese banks during the pandemic.

The results in Pakistan show that only HCE positively impacts $\operatorname{ROA}(\beta=0.009, t=7.244)$ and $\operatorname{ROE}(\beta=0.011$, $t=3.847$ ), which is consistent with Rehman et al. [64]. However, CEE and HCE have a positive influence only on the ROE indicator. These results also suggest that, like Chinese banking industry, HCE is also a major driver of Pakistani banks' profitability during the COVID-19 period. Zhu and Shah [65] and Xu et al. [66] confirmed that the operational efficiency of Chinese commercial banks is higher than that of Pakistani counterparts.

4.3. Robustness Check. Although the empirical findings are robust to two profitability indicators (ROA and ROE), we also use the modified VAIC (MVAIC) model with the inclusion of relational capital to measure IC for further robustness of this study. Robustness check results are presented in Table 5. The MVAIC is the sum of CEE, HCE, SCE, and relational capital efficiency (RCE). RCE is calculated as the ratio of selling expenses and VA. In the full sample, we find that MVAIC has a significant positive correlation with ROA and ROE. Further, in China and Pakistan, there exists a positive relationship between MVAIC and bank profitability. This suggests that our conclusion is robust.

\section{Discussion}

The current study analyzes the IC performance in two emerging economies (China and Pakistan) whose banking systems are still in the early stages of growth during the COVID-19 period. The findings suggest that IC keeps its positive impact on banks' profitability during the pandemic period in both countries. This could be explained by the fact that both countries have successfully controlled the impact of the COVID-19 pandemic. Unlike other economies around the globe, these two countries did not put their countries into full lockdown. China has controlled the spread of COVID-19 within two months of its outbreak, while Pakistan has also managed to control its quick spread by implementing smart lockdown in different periods. Because of the smart lockdown, banking and other industries remained operational throughout the COVID-19 pandemic, which enabled them to generate wealth from their IC resources.

In the Chinese context, CEE has a positive but insignificant impact on profitability, and SCE exerts a negative impact on only ROA. However, HCE positively affects Chinese banks' profitability. One possible explanation is that during the COVID-19 crisis, Chinese banks paid much more attention to the role of $\mathrm{HC}$ compared to physical and structural capitals. However, in the case of Pakistan, CEE and SCE significantly improve only the ROE indicator, while HCE contributes to raising performance in terms of ROA and ROE. Overall, our findings suggest that $\mathrm{HC}$ is the only IC resource that has a vital role in generating profits in two countries even during such a crisis, which is in line with previous studies $[15,46]$. This could be caused by the investment in knowledge, skills, imagination, capabilities, experiences, and intellectual agility of all bank employees. Previously, Meles et al. [34] and Ozkan et al. [67] also found that $\mathrm{HC}$ is the only IC resource, which has a positive impact on bank profitability. The weaker impact of CEE and SCE on bank profitability in these two countries could be because of less attention on culture, system, procedures, database, and networks during the crisis caused by COVID-19. The results demonstrate that banks need high concentration on IC to improve profitability, minimize economic stress, and gain financial performance. In particular, $\mathrm{HC}$ has a very strong value creation ability for banks in both countries; thus, it is important for banks to invest in human recourses that are competent, knowledgeable, and professional.

Additionally, Al-Kharusu and Murthy [68] found that several banks experienced financial instability during periods of economic turbulence caused by COVID-19. The findings of Elnahass et al. [69] showed that the COVID-19 outbreak brought detrimental impacts on financial performance and financial stability in the global banking system. Grasselli [70] pointed out that the intervention of central banks can deal with the COVID-19 financial and economic crisis by lowering interest rates and lending to financial institutions. Korzeb and Niedziółka [71] concluded that large banks with more resources are resistant to this crisis resulting from the COVID-19 pandemic. Mateev et al. [72] confirmed that banks should build a sufficient capital conservation buffer during the COVID-19 pandemic. Banna and Alam [73] suggested that the application of digital finance is significant for maintaining banking sector stability even in the face of any crisis. A survey in central, eastern, and northern Europe also showed that banks implemented digital transformation during the COVID-19 pandemic [74]. 
TABLE 5: Regression results of robustness check.

\begin{tabular}{|c|c|c|c|c|c|c|}
\hline \multirow{2}{*}{ Variable } & \multicolumn{2}{|c|}{ Full sample } & \multicolumn{2}{|c|}{ China } & \multicolumn{2}{|c|}{ Pakistan } \\
\hline & Model (1) & Model (2) & Model (1) & Model (2) & Model (1) & Model (2) \\
\hline Constant & $\begin{array}{c}-0.025^{* * *} \\
(-5.050)\end{array}$ & $\begin{array}{c}-0.079^{* * *} \\
(-2.965)\end{array}$ & $\begin{array}{c}-0.074^{* * *} \\
(-12.150)\end{array}$ & $\begin{array}{c}-0.604^{* * *} \\
(-11.123)\end{array}$ & $\begin{array}{c}0.003 \\
(0.226)\end{array}$ & $\begin{array}{l}-0.129^{*} \\
(-1.906)\end{array}$ \\
\hline MVAIC & $\begin{array}{c}0.003^{* * *} \\
(6.633)\end{array}$ & $\begin{array}{c}0.014^{* * *} \\
(5.480)\end{array}$ & $\begin{array}{l}0.001^{* * *} \\
(14.249)\end{array}$ & $\begin{array}{c}0.007^{* * *} \\
(7.598)\end{array}$ & $\begin{array}{c}0.006^{* * * *} \\
(6.042)\end{array}$ & $\begin{array}{c}0.028^{* * * *} \\
(5.628)\end{array}$ \\
\hline SIZE & $\begin{array}{c}0.000 \\
(-1.132)\end{array}$ & $\begin{array}{c}0.004^{* * *} \\
(3.294)\end{array}$ & $\begin{array}{c}0.000 \\
(-0.896)\end{array}$ & $\begin{array}{c}-0.001 \\
(-0.513)\end{array}$ & $\begin{array}{c}-0.002^{* * *} \\
(-3.154)\end{array}$ & $\begin{array}{c}0.004 \\
(1.120)\end{array}$ \\
\hline LEV & $\begin{array}{c}0.029^{* * * *} \\
(8.775)\end{array}$ & $\begin{array}{l}0.033^{*} \\
(1.887)\end{array}$ & $\begin{array}{c}0.086^{* * *} \\
(11.027)\end{array}$ & $\begin{array}{c}0.763^{* * *} \\
(10.915)\end{array}$ & $\begin{array}{c}0.029^{* * *} \\
(6.748)\end{array}$ & $\begin{array}{c}0.017 \\
(0.789)\end{array}$ \\
\hline OWN & $\begin{array}{c}-0.004 \\
(-1.423)\end{array}$ & $\begin{array}{c}-0.006 \\
(-0.481)\end{array}$ & $\begin{array}{c}0.000 \\
(0.585)\end{array}$ & $\begin{array}{l}-0.006 \\
(-1.014)\end{array}$ & $\begin{array}{c}-0.002 \\
(-0.376)\end{array}$ & $\begin{array}{c}0.035 \\
(1.459)\end{array}$ \\
\hline $\mathrm{N}$ & 219 & 219 & 102 & 102 & 117 & 117 \\
\hline Adj. $R^{2}$ & 0.364 & 0.224 & 0.759 & 0.644 & 0.426 & 0.251 \\
\hline $\mathrm{F}$ & $32.171^{* * *}$ & $16.718^{* * *}$ & $80.369^{* * *}$ & $46.644^{* * *}$ & $22.495^{* * *}$ & $10.719^{* * *}$ \\
\hline
\end{tabular}

Note: ${ }^{*} p<0.10,{ }^{* *} p<0.05$, and ${ }^{* * *} p<0.01 . t$-values are in parentheses.

\section{Conclusions}

In today's knowledge-based economy, IC is widely recognized as a source of competitiveness and future value creation. However, the ongoing health crisis has affected the mechanism of value creation from IC resources and the sustained profitability of institutions around the globe. This study examines the relationship between IC and its components and bank profitability (measured through ROA and ROE) during COVID-19 in the context of Chinese and Pakistani banks. The empirical results demonstrate that IC sustains its positive impact on bank profitability in China and Pakistan during the COVID-19 era. Among IC components, the impact of $\mathrm{HC}$ on ROA and ROE of both Chinese and Pakistani banks is significant and positive, and SC positively affects the ROE of Pakistani banks and negatively affects the ROA of Chinese banks. HCE seems to be the most important factor that continues to influence higher profitability in the case of the Chinese and Pakistani banking sectors, even during the pandemic. In addition, physical capital is found to sustain its positive influence on the ROE of Pakistani banks during a pandemic. However, it has also sustained its positive but insignificant influence on the profitability of Chinese banks.

Theoretically, the contribution of our study is of high importance. This crisis is the most concerning matter to control for all economies around the globe because it has detracted the economic wheel of all economies. Hence, almost every resource of every institution suffered globally because of the current COVID-19 crisis, thus influencing the institutional performance. Therefore, our study first examines the impact of IC resources on the profitability of Chinese and Pakistani banks during the COVID-19 period. Based on the quarterly data of 34 Chinese and 39 Pakistani banks during the pandemic period, this study uses the VAIC method as the measure of IC performance and uses ROA and ROE as the proxy for profitability. Further, the study also uses bank size, bank leverage, and bank ownership as the control variables to offer robust and corrected inferences. Based on the findings, the study has provided some important practical implications for bank managers, regulators, and policymakers. It suggests that IC is the most important among all resources, which seems to always play its positive role in sustaining the shocks from unforeseen crises and thus ensures the profitability of banking institutions. Therefore, we suggest that investing more in IC resources has a high probability of enhancing the profitability of banks even during the ongoing pandemic. Our findings provide guidelines to develop strategies for investment in the IC resources, especially $\mathrm{HC}$. Investment in human skills and competencies can enhance service quality, diversify operations, and improve the overall financial efficiency because the strong skills and competencies of employees prevent financial institutions from the adverse impact of economic shocks. Finally, the empirical results suggest that the utilization of physical and structural capitals still demands great attention to make them able to play their preventing role for sustaining the improved profitability.

The current research also has some limitations that may pave the way for future studies. First, the empirical results focus on the banking sector in two countries, and future research could extend the analysis to include other financial sectors or banks functioning in other countries. Secondly, it would be helpful to extend the more recent and historical data because the inclusion of recent data will help assess the IC performance dynamics during and after the COVID-19 crisis. It could also be useful for future studies to link the role of governance with IC and profitability during the pandemic period.

\section{Data Availability}

The data used to support the findings of this study are available from the corresponding author upon request.

\section{Conflicts of Interest}

The authors declare that they have no conflicts of interest.

\section{Acknowledgments}

The research was funded by the Shandong Provincial $\mathrm{Hu}-$ manities and Social Sciences Research Project (Grant no. 
2021-YYGL-09) and the Scientific Research Foundation for High-Level Talents of Qingdao Agricultural University (Grant no. 6631120701).

\section{References}

[1] R. Waheed, S. Sarwar, S. Sarwar, and M. K. Khan, "The impact of COVID-19 on Karachi stock exchange: quantile-onquantile approach using secondary and predicted data," Journal of Public Affairs, vol. 20, no. 4, Article ID e2290, 2020.

[2] M. Just and K. Echaust, "Stock market returns, volatility, correlation and liquidity during the COVID-19 crisis: evidence from the Markov switching approach," Finance Research Letters, vol. 37, Article ID 101775, 2020.

[3] J. W. Goodell, "COVID-19 and finance: agendas for future research," Finance Research Letters, vol. 35, Article ID 101512, 2020.

[4] W. McKibbin and R. Fernando, "The global macroeconomic impacts of COVID-19: seven scenarios," Asian Economic Papers, vol. 20, no. 2, pp. 1-30, 2021.

[5] M. Fu and H. Shen, "COVID-19 and corporate performance in the energy industry," Energy RESEARCH LETTERS, vol. 1, no. 1, pp. 1-5, 2020.

[6] A. Haque and S. Sarwar, "Effect of fundamental and stock market variables on equity return in Pakistan," Science International, vol. 25, no. 4, pp. 981-987, 2013.

[7] R. Waheed, C. Wei, S. Sarwar, and Y. Lv, "Impact of oil prices on firm stock return: industry-wise analysis," Empirical Economics, vol. 55, no. 2, pp. 765-780, 2018.

[8] M. Ashfaq and M. Bashir, "Pakistan: making a "COVID budget" in a struggling economy," Journal of Public Budgeting, Accounting and Financial Management, vol. 33, no. 1, pp. 69-77, 2021.

[9] W. G. Carlos, C. S. Dela Cruz, B. Cao, S. Pasnick, and S. Jamil, "Novel wuhan (2019-nCoV) coronavirus," American Journal of Respiratory and Critical Care Medicine, vol. 201, no. 4, pp. P7-P8, 2020.

[10] Y. Bai, L. Yao, T. Wei et al., "Presumed asymptomatic carrier transmission of COVID-19," JAMA, vol. 323, no. 14, pp. 1406-1407, 2020.

[11] J. Chen, Z. H. Feng, L. Ye et al., "Travel rush during Chinese spring festival and the 2019-nCoV," Travel Medicine and Infectious Disease, vol. 37, Article ID 101686, 2020.

[12] X. Xiao, X. Zhu, S. Fu, Y. Hu, X. Li, and J. Xiao, "Psychological impact of healthcare workers in China during COVID-19 pneumonia epidemic: a multi-center cross-sectional survey investigation," Journal of Affective Disorders, vol. 274, pp. 405-410, 2020.

[13] V. Lefter, N. Istudor, M. Prejmerean, and C. Dobrin, "Intellectual capital in the metallurgical industry solutions to the financial crisis and regional development," Metalurgia International, vol. 14, pp. 19-24, 2009.

[14] L. Craciun, "Intellectual capital-Generator of sustainable competitive advantage for coming out of the crisis," Revista Economica, vol. 55, no. 2, pp. 159-161, 2011.

[15] S. Kehelwalatenna, "Intellectual capital performance during financial crises," Measuring Business Excellence, vol. 20, no. 3, pp. 55-78, 2016.

[16] T. Nawaz, "Intellectual capital, financial crisis and performance of Islamic banks: does Shariah governance mater?" International Journal of Business and Society, vol. 18, no. 1, pp. 211-226, 2017.
[17] A. Pulic, "VAIC ${ }^{\mathrm{TM}}$-an accounting tool for IC management," International Journal of Technology Management, vol. 20, no. 5-8, pp. 702-714, 2000.

[18] L. Edvinsson, "Developing intellectual capital at Skandia," Long Range Planning, vol. 30, no. 3, pp. 366-373, 1997.

[19] F. Sardo and Z. Serrasqueiro, "Intellectual capital, growth opportunities, and financial performance in European firms," Journal of Intellectual Capital, vol. 19, no. 4, pp. 747-767, 2018.

[20] A. E. Bayraktaroglu, F. Calisir, and M. Baskak, "Intellectual capital and firm performance: an extended VAIC model," Journal of Intellectual Capital, vol. 20, no. 3, pp. 406-425, 2019.

[21] A. Dean and M. Kretschmer, "Can ideas Be capital? Factors of production in the postindustrial economy: a review and critique," Academy of Management Review, vol. 32, no. 2, pp. 573-594, 2007.

[22] J. Dumay, J. Guthrie, and P. Puntillo, "IC and public sector: a structured literature review," Journal of Intellectual Capital, vol. 16, no. 2, pp. 267-284, 2015.

[23] M. A. Youndt, M. Subramaniam, and S. A. Snell, "Intellectual capital profiles: an examination of investments and returns," Journal of Management Studies, vol. 41, no. 2, pp. 335-361, 2004.

[24] A. Kianto, P. Hurmelinna-Laukkanen, and P. Ritala, "Intellectual capital in service- and product-oriented companies," Journal of Intellectual Capital, vol. 11, no. 3, pp. 305-325, 2010.

[25] N. Bontis, W. Chua Chong Keow, and S. Richardson, "Intellectual capital and business performance in Malaysian industries," Journal of Intellectual Capital, vol. 1, no. 1, pp. 85-100, 2000.

[26] L. Edvinsson and M. S. Malone, Intellectual Capital: Realizing Your Company's True Value by Finding its Hidden Brainpower, Harper Business, New York, NY, USA, 1997.

[27] N. Bontis, "Intellectual capital: an exploratory study that develops measures and models," Management Decision, vol. 36, no. 2, pp. 63-76, 1998.

[28] G. Martín-de-Castro, M. Delgado-Verde, P. López-Sáez, and J. E. Navas-López, “Towards 'an intellectual capital-based view of the firm': origins and nature," Journal of Business Ethics, vol. 98, no. 4, pp. 649-662, 2011.

[29] C.-H. Liu, "Creating competitive advantage: linking perspectives of organization learning, innovation behavior and intellectual capital," International Journal of Hospitality Management, vol. 66, pp. 13-23, 2017.

[30] I. Ting and H. H. Lean, "Intellectual capital performance of financial institutions in Malaysia," Journal of Intellectual Capital, vol. 10, no. 4, pp. 588-599, 2009.

[31] S. Firer and S. Mitchell Williams, "Intellectual capital and traditional measures of corporate performance," Journal of Intellectual Capital, vol. 4, no. 3, pp. 348-360, 2003.

[32] S. Saengchan, "The role of intellectual capital in creating value in the banking industry," International Review of Business Research, vol. 7, no. 2, pp. 157-169, 2008.

[33] K. N. I. K. Ismail and M. A. Karem, "Intellectual capital and the financial performance of banks in Bahrain," Journal of Business Management and Accounting, vol. 1, no. 1, pp. 63-77, 2011.

[34] A. Meles, C. Porzio, G. Sampagnaro, and V. Verdoliva, "The impact of the intellectual capital efficiency on commercial banks performance: evidence from the US," Journal of Multinational Financial Management, vol. 36, pp. 64-74, 2016. 
[35] J. Mohammad, S. Tobiagi, and R. Abdul Razak, "Intellectual capital disclosures practices and intellectual capital performance in Saudi arabia financial institution," Journal of Business Studies Quarterly, vol. 7, pp. 1-14, 2016.

[36] D. B. Tran and D. H. Vo, "Should bankers be concerned with Intellectual capital? A study of the Thai banking sector," Journal of Intellectual Capital, vol. 19, no. 5, pp. 897-914, 2018.

[37] H. Yao, M. Haris, G. Tariq, H. M. Javaid, and M. A. S. Khan, "Intellectual capital, profitability, and productivity: evidence from Pakistani financial institutions," Sustainability, vol. 11, no. 14 , p. $3842,2019$.

[38] J. Xu, M. Haris, and H. Yao, "Should listed banks Be concerned with intellectual capital in emerging asian markets? A comparison between China and Pakistan," Sustainability, vol. 11, no. 23, p. 6582, 2019.

[39] M. I. Nazir, Y. Tan, and M. R. Nazir, "Intellectual capital performance in the financial sector: evidence from China, Hong Kong, and Taiwan," International Journal of Finance \& Economics, vol. 26, no. 4, pp. 6089-6109, 2021.

[40] P. Chen Goh, "Intellectual capital performance of commercial banks in Malaysia," Journal of Intellectual Capital, vol. 6, no. 3, pp. 385-396, 2005.

[41] A. Mondal and S. K. Ghosh, "Intellectual capital and financial performance of Indian banks," Journal of Intellectual Capital, vol. 13, no. 4, pp. 515-530, 2012.

[42] M. Joshi, D. Cahill, J. Sidhu, and M. Kansal, "Intellectual capital and financial performance: an evaluation of the Australian financial sector," Journal of Intellectual Capital, vol. 14, no. 2, pp. 264-285, 2013.

[43] D. H. Vo and N. P. Tran, "Intellectual capital and bank performance in Vietnam," Managerial Finance, vol. 47, no. 8, pp. 1094-1106, 2021.

[44] M. Mazur, M. Dang, and M. Vega, "COVID-19 and the march 2020 stock market crash. Evidence from S\&P1500," Finance Research Letters, vol. 38, Article ID 101690, 2021.

[45] S. Sumedrea and F. Performance, "Intellectual capital and firm performance: a dynamic relationship in crisis time," Procedia Economics and Finance, vol. 6, pp. 137-144, 2013.

[46] G. Sannino, G. Nicolò, and G. Zampone, "The impact of intellectual capital on bank performance during and after the NPLs crisis: evidence from Italian banks," International Journal of Applied Decision Sciences, vol. 14, no. 4, pp. 419442, 2021.

[47] A. Demirgüç-Kunt, A. Pedraza, and C. Ruiz-Ortega, "Banking sector performance during the COVID-19 crisis," Journal of Banking \& Finance, vol. 133, Article ID 106305, 2021.

[48] L. Katusiime, "COVID 19 and bank profitability in low income countries: the case of Uganda," Journal of Risk and Financial Management, vol. 14, no. 12, p. 588, 2021.

[49] E. A. Al-Homaidi, M. I. Tabash, N. H. S. Farhan, and F. A. Alnnaqtari, "Bank-specific and macro-economic determinants of profitability of Indian commercial banks: a panel data approach," Cogent Economics \& Finance, vol. 6, no. 1, Article ID 1548072, 2018.

[50] F. A. Almaqtari, E. A. Al-Homaidi, M. I. Tabash, and N. H. Farhan, "The determinants of profitability of Indian commercial banks: a panel data approach," International Journal of Finance \& Economics, vol. 24, no. 1, pp. 168-185, 2019.

[51] A. Buallay, R. Cummings, and A. Hamdan, "Intellectual capital efficiency and bank's performance," Pacific Accounting Review, vol. 31, no. 4, pp. 672-694, 2019.

[52] M. Haris, H. Yao, G. Tariq, A. Malik, and H. Javaid, "Intellectual capital performance and profitability of banks: evidence from Pakistan," Journal of Risk and Financial Management, vol. 12, no. 2, p. 56, 2019.

[53] E. A. A. Homaidi, F. A. Almaqtari, A. T. Yahya, and A. S. D. Khaled, "Internal and external determinants of listed commercial banks' profitability in India: dynamic GMM approach," International Journal of Monetary Economics and Finance, vol. 13, no. 1, pp. 34-67, 2020.

[54] H.-u. Rahman, M. W. Yousaf, and N. Tabassum, "Bankspecific and macroeconomic determinants of profitability: a revisit of Pakistani banking sector under dynamic panel data approach," International Journal of Financial Studies, vol. 8, no. 3, p. $42,2020$.

[55] N. Soewarno and B. Tjahjadi, "Measures that matter: an empirical investigation of intellectual capital and financial performance of banking firms in Indonesia," Journal of Intellectual Capital, vol. 21, no. 6, pp. 1085-1106, 2020.

[56] J. Xu and J. Li, "The impact of intellectual capital on SMEs' performance in China," Journal of Intellectual Capital, vol. 20, no. 4, pp. 488-509, 2019.

[57] J. Xu and J. Li, “The interrelationship between intellectual capital and firm performance: evidence from China's manufacturing sector," Journal of Intellectual Capital, 2020.

[58] J. Xu, F. Liu, and F. Liu, "The impact of intellectual capital on firm performance: a modified and extended VAIC model," Journal of Competitiveness, vol. 12, no. 1, pp. 161-176, 2020.

[59] J. Xu and Y. Zhang, "Exploring the nonlinear effect of intellectual capital on financial performance: evidence from listed shipping companies in China," Complexity, vol. 2021, Article ID 9004907, 12 pages, 2021.

[60] L. Zhang, Q. Yu, Z. J. Jin, and J. Xu, "Do intellectual capital elements spur firm performance? Evidence from the textile and apparel industry in China," Mathematical Problems in Engineering, vol. 2021, Article ID 7332885, 12 pages, 2021.

[61] A. Subbarayan and J. Jothikumar, "Bank specific, industry specific and macro economic determinants of profitability of public sector banks in India: 2010-2016-A panel data approach," International Journal of Agricultural and Statistical Sciences, vol. 13, no. 2, pp. 655-662, 2017.

[62] A. A. Ousama, H. Hammami, and M. Abdulkarim, "The association between intellectual capital and financial performance in the Islamic banking industry an analysis of the GCC banks," International Journal of Islamic and Middle Eastern Finance and Management, vol. 13, no. 1, pp. 75-93, 2020.

[63] T. D. Q. Le and D. T. Nguyen, "Intellectual capital and bank profitability: new evidence from Vietnam," Cogent Business \& Management, vol. 7, no. 1, Article ID 1859666, 2020.

[64] W. U. Rehman, H. U. Rehman, M. Usman, and N. Asghar, "A link of intellectual capital performance with corporate performance: comparative study from banking sector in Pakistan," International Journal of Business and Social Science, vol. 3, no. 12, pp. 313-321, 2012.

[65] N. Zhu and W. U. H. Shah, "A cross-country comparison of operational efficiency between Chinese and Pakistani commercial banking industries," International Journal of Operational Research/Nepal, vol. 8, no. 1, pp. 1-11, 2019.

[66] J. X. Xu, N. Li, and M. I. Ahmad, "Banking performance of China and Pakistan," Entrepreneurship and Sustainability Issues, vol. 5, no. 4, pp. 929-942, 2018.

[67] N. Ozkan, S. Cakan, and M. Kayacan, "Intellectual capital and financial performance: a study of the Turkish Banking Sector," Borsa Istanbul Review, vol. 17, no. 3, pp. 190-198, 2017.

[68] S. Al-Kharusi and S. R. Murthy, "Financial stability of gcc banks in the COVID-19 crisis: a simulation approach," The 
Journal of Asian Finance, Economics and Business, vol. 7, no. 12, pp. 337-344, 2020.

[69] M. Elnahass, V. Q. Trinh, and T. Li, "Global banking stability in the shadow of Covid-19 outbreak," Journal of International Financial Markets, Institutions and Money, vol. 72, Article ID 101322, 2021.

[70] M. R. Grasselli, "Monetary policy responses to covid-19: a comparison with the 2008 crisis and implications for the future of central banking," Review of Political Economy, 2021.

[71] Z. Korzeb and P. Niedziółka, "Resistance of commercial banks to the crisis caused by the COVID-19 pandemic: the case of Poland," Equilibrium, vol. 15, no. 2, pp. 205-234, 2020.

[72] M. Mateev, M. U. Tariq, and A. Sahyouni, "Competition, capital growth and risk-taking in emerging markets: policy implications for banking sector stability during COVID-19 pandemic," PLoS One, vol. 16, no. 6, Article ID e0253803, 2021.

[73] H. Banna and M. R. Alam, "Impact of digital financial inclusion on ASEAN banking stability: implications for the post-Covid-19 era," Studies in Economics and Finance, vol. 38, no. 2, pp. 504-523, 2021.

[74] E. Miklaszewska, K. Kil, and M. Idzik, "How the COVID-19 pandemic affects bank risks and returns: evidence from EU members in central, eastern, and northern Europe," Risks, vol. 9, no. 10, p. 180, 2021. 